\title{
Measuring Sources of Economic Growth in OECD Countries
}

\author{
Marinko Skare, Danijela Rabar
}

Juraj Dobrila University of Pula

Zagrebacka 30, 52100 Pula, Croatia

E-mail.mskare@unipu.hr,drabar@unipu.hr

cross $^{\text {ref }}$ http://dx.doi.org/10.5755/j01.ee.28.4.18502

\begin{abstract}
Growing socioeconomic inequalities and deepening polarization among and within nations indicate a major risk of political, social and economic instability. Policymakers need to deepen their awareness and understanding of the circumstances and find useful guidance and examples to inspire their effective qualitative and quantitative policies. This paper empirically investigates the relative dynamic socio-economic efficiency of thirty OECD countries using Data Envelopment Analysis (DEA) methodology. As an extension to the basic output-oriented DEA models with variable returns-to-scale, window analysis is employed. The appropriate design of window length is also proposed in the study. In the first step, the relative efficiency of the countries was measured by four economic indicators. In the second step, four new indicators were added, covering social, institutional and environmental dimensions. It has been found that, in some cases, performance rankings change very significantly and that the overall relative performance of the OECD countries increases when the set of economic indicators is extended.
\end{abstract}

Keywords: Growth, Cross-Country, OECD, Efficiency, Data Envelopment Analysis, Window Analysis.

\section{Introduction}

Global inequality has been the subject of intense debate, as different data sources show different levels and trends. Nevertheless, development gap between wealthy and poor countries undoubtedly exists, and many differences in growth rates of countries can be found even in the same region. The aim of this study is to show that DEA method used in economic growth analysis offers robust and valuable results. This paper is among few to employ DEA method in studying economic growth.

According to the IMF, the Great Recession at the end of the first decade of the 21st century was the worst global recession since World War II. This economic crisis highlighted the urgency to address multiple and widening socio-economic inequalities, health (Jakubowska \& Horvathova, 2016) and development gaps, both between and within countries, which is crucial for moving beyond embracing disproportionality and disparities and for implementing a growth model driven by equity. This is of utmost importance, especially for less developed regions, to raise the quality of life and living standards. Therefore, the interest in measuring and assessing the macroeconomic performance of nations is growing, and growth analysts are supposed to identify the reasons behind mentioned imbalances. Practical insight into the core of this problem may be provided by the integration of theory and empirics.

A high real GDP growth rate, a low rate of inflation, a low rate of unemployment and a favourable external account are four main objectives of a nation's macroeconomic policymakers. It has become common practice to summarize the economic performance of countries regarding these four performance indices that are referred to in the literature as the "magic diamond" of OECD (Organisation for Economic Cooperation and Development) (Lovell et al., 1995). Defined as the sum of the inflation rate and the unemployment rate, the undesirable "Misery Index" (McCracken et al., 1977), created by Okun (1970), provides a pessimistic measure of the macroeconomic performance of nations. An undesirable alternative measure, known as the Calmfors-Driffill Index, developed by Calmfors \& Driffill (1988), is provided by the difference between the unemployment rate and the GDPnormalized trade balance. These three approaches have two main shortcomings. Firstly, the Misery Index and the Calmfors-Driffill Index have only two dimensions, while the Magic Diamond is four-dimensional. Although all the employed conventional economic indicators are admittedly informative, they are flawed and outdated with regard to the tremendous social challenges that contemporary socioeconomic systems are facing. To overcome this drawback, social as well as institutional and environmental aspects of economic development should also be considered. Secondly, all three measures assign equal unitary weights to their components. Such arbitrary weighting scheme is unduly restrictive, which constitutes the major drawback of these approaches. The solution is the concept of data envelopment analysis which allows the use of multiple inputs and outputs and ensures a weighting scheme with non-arbitrary weights that are allowed to vary over components, across countries and through time. The results of this paper show DEA method to perform surprisingly well when compared to the Panel, VAR/VARMA and Bayesian. DEA method allows economic growth researchers to study the effects of social, institutional and environmental changes on economic growth that otherwise are more difficult to assess when using standard growth econometric models.

A narrow-sided view of well-being, which implicitly identifies global inequality with global income inequality, ignores various sources of heterogeneity in other dimensions 
of life, such as education, health, and climate. Moreover, the initiative of developing "beyond GDP" indicators that are as clear as GDP but more inclusive of environmental and social aspects of progress, is attracting more and more scientific attention as a response to global challenges of the $21^{\text {st }}$ century. By embracing these and other disparities between countries, the aim of this paper is to determine, to measure and to compare the main sources of economic growth in OECD countries, and to reveal the relationship between the extent of inequality and economic growth. A model of economic growth will be explored for the period 2002-2011, using DEA as a nonparametric cross-country time-series approach and employing output-oriented models with variable returns-to-scale. The paper is organized as follows. The next section gives a brief overview of the literature on the measurement of socio-economic development across OECD countries based on the use of DEA method. Section 3 presents the selected socio-economic indicators and describes the DEA method setting up a methodological framework for the study. Empirical results of the DEA application for the relative efficiency assessment of OECD members are presented in section 4 . Section 5 summarizes the findings of the research and presents general remarks about their implications for policymakers.

\section{Literature Review}

Over the last decades, a large body of empirical economic literature has been dealing with cross-country socioeconomic performance comparison and evaluation, aiming to find which countries perform better, to identify main problems and challenges and to suggest possible solutions. Here is a brief summary of the literature related to economic growth and its determinants across OECD members, based on the use of a number of different DEA-inspired approaches. It should be mentioned that the use of data envelopment analysis as a tool for macroeconomic analysis was pioneered by the work of Färe et al. (1994), which addressed precisely the OECD countries. VARMA models prove to be a valuable tool in forecasting macroeconomic indicators (Simionescu, 2013). Bayesian model, an alternative tool in studying economic growth determinants, (Blazejowski et al., 2016) show increasing accuracy in measuring regional economic growth differences.

The literature on socio-economic performance across OECD countries, using DEA, can be divided into three groups based on the indicators used. Studies from the first group focus on economic indicators (Färe et al., 1994; Moesen \& Cherchye, 1998; Brockett et al., 1999; Maudos et al., 1999; Arcelus \& Arocena, 2000; Cherchye, 2001; Emrouznejad, 2003; Afonso \& St. Aubyn, 2013). In most cases, these indicators are GDP, capital stock, and employment. Studies from the second group accentuate the importance of environmental issues (Streimikiene, 2016), employing economic and ecological indicators (Lovell et al., 1995; Zaim \& Taskin, 2000; Zofio \& Prieto, 2001; Arcelus \& Arocena, 2005; Barla \& Perelman, 2005; Camarero et al., 2008; Halkos \& Tzeremes, 2009; Camarero et al., 2013; Lu et al., 2013). The undesirable indicators related to environmental problems are usually emissions to the environment, mostly carbon, nitrogen and sulphur.
In addition to individual findings pertaining to specific countries, the following general conclusions can be drawn from these studies. When observing economic indicators, more developed OECD countries expectedly are ranked higher than less developed ones. However, after adding undesirable environmental indicators, performance rankings change, and the relative performance of most developed countries declines. Therefore, an increase in GDP per capita should be unequivocally associated with a growing demand for higher environmental quality. Moreover, due to the robust and positive correlation between energy consumption and undesirable outputs, countries producing high undesirable outputs have an extreme potential to save the optimum energy. Studies from the third group underline the significance of energy supply and/or consumption, usually combining three types of indicators - economic, environmental and energetic (Färe $e t$ al., 2004; Zhou et al., 2006; Zhou et al., 2007; Zhou \& Ang, 2008; Simsek, 2014; Rashidi et al., 2015; Rashidi \& Saen, 2015; Woo et al., 2015), (Makridou et al., 2016), (Sueyoshi et al., 2017), (Mardani et al., 2015). The most employed energetic indicators are different types of energy consumption (oil, gas, coal, power). It may be said, roughly speaking, that researchers progressively shifted their focus from economic efficiency in the 1990s to environmental efficiency in 2000s, and then to energy efficiency in 2010 s. International institutions' financial assistance program effect on the economic growth is important just in the long run (Fidrmuc \& Kostagianni, 2015). Panel data model applied for studying economic growth determinants in the EU (Simionescu et al., 2016) show lagged GDP growth rate to have the largest effect on the current economic growth (along with the employment rate).

\section{Data and Methodological Framework}

The OECD countries represent thirty entities whose relative socio-economic performance is evaluated in this research. This research includes 30 of the 34 current OECD member countries. Namely, Chile, Estonia, Israel and Slovenia are excluded from the analysis due to the fact that these countries became OECD members shortly before the end of the period under study. Although the size and organizational structure of the bureaucracy responsible for the conduct of macroeconomic policies in each country, as well as the scale of the observed socio-economic indicators, vary significantly across countries and over time, it is not considered relevant for our purpose. Namely, what matters are bureaucracy's macroeconomic performance and the relationship between the inputs used and outputs produced by each country, which will be compared across countries.

\section{Inputs and Outputs Selection}

A different choice of observed indicators results with different relative efficiency scores that are, and in some cases, significantly, affected by model choice. Therefore, the right selection of appropriate inputs and outputs is one of the most important and most difficult steps in designing an adequate empirical model for assessing the relative performance of countries. Being crucial for the analysis, the choice of variables should address the multidimensional 
phenomenon of economic growth as accurately as possible and, consequently, precisely portray overall performance of countries. Moreover, often conflicting demands and appraisals of researchers and policymakers should also be reflected and reconciled. A major requirement for the model is to be appropriate for the process under study.

No single indicator concerns all determinants that are relevant to define strategic and operational aims of sustainable countries' development, and to analyse it over time systematically. It is, therefore, necessary to set the proper indicators of a complex phenomenon of sustainable development with a goal to integrate economic, social, institutional and ecological subsystem into a whole, taking care of their mutual influence. Setting the model was preceded by consideration of a broad spectrum of socioeconomic indicators that are relevant to the analysis of countries' development. The constraining criteria that ruled the selection of indicators included demands for their exact measurability and the availability and accessibility of data. At the same time, human, material, and institutional resources, as well as living standards, should inevitably be taken into consideration.

After ranking the importance of the considered indicators, the following socio-economic factors were chosen: gross domestic product (GDP), inflation rate, unemployment rate, exports/imports cover ratio, carbon dioxide (CO2) emissions, scientific and technical journal articles, public health expenditure and seats held by women in national parliaments. The following is a brief description of these indicators.

- GDP is accepted as a measure of living standard and traditionally regarded as the best indicator of the economic performance of a country. Since the aim of this study is to compare different countries over time, real per capita GDP can be considered the most suitable pointer of economic growth. Data are in constant 2005 U.S. dollars.

- The inflation rate is taken into consideration as a key indicator of macroeconomic stability, used in many crosscountry studies, some of which mentioned in this paper. It is here measured by the annual growth rate of the GDP implicit deflator.

- Although unemployment is typically considered a lagging indicator of the business cycle, the unemployment rate, expressed as the percentage of unemployed people in the labour force, is used as a key indicator of socioeconomic well-being.

- International exchange, as a component of economic openness, plays a major role in boosting economic growth. To make cross-country disparities better explainable and comparisons more reliable, it is here represented by a cover ratio, calculated as the ratio of exports to imports and expressed as a percentage.

- Given the increasing global concern about climate change and preserving the environment, $\mathrm{CO} 2$ emissions to the atmosphere are incorporated as an indicator of greenhouse gas emissions. They are here measured in millions of tons per capita.

- An efficient and productive research and development (R\&D) is one of the primary sources of the competitiveness of modern society. Within this context, publications are the major output of scientific research and are used to evaluate the performance of researchers in many countries (OECD, 2001). They are here expressed as the number of scientific and technical journal articles per 100,000 people. This number includes all scientific and engineering articles published in the fields of physics, biology, chemistry, mathematics, clinical medicine, biomedical research, engineering and technology, and earth and space sciences.

- Health expenditure is frequently used in international comparisons as the indicator of inputs to the health sector. Public healthcare is often the cornerstone of the healthcare system, acting as the safety net for the whole community. Therefore, the proportion of public money in total health care expenditure is often employed as an important indicator of government commitment to health and social development in general. Hence public health expenditure expressed as a percentage of total health expenditure is chosen to give a basic picture of health care systems characteristics.

To strengthen the efforts of today's world to fight poverty, the Millennium Development Goals (MDGs) were established by the United Nations in 2000. These are eight goals with time-bound and measurable targets, signed by the leaders of 189 countries. Within the goal of promoting gender equality and empowering women, the number of women in national parliaments was included as an indicator. Although not providing comprehensive insight into the level of women's power and influence in society, the proportion of seats held by women in national parliament is here chosen as a considered indicator of gender equality which positively affects political democracy, leading to political responsibility, social maturity and growth. This indicator changes slowly over time, which makes it insensitive to short term fluctuations and policy changes and therefore unsuitable to be considered over a successive period. Despite this, it is included into analysis because during a decade-long period there may occur significant changes, as evidenced by examples of Turkey, Italy, Greece, etc.

\section{Data}

Data for the selected eight variables are relating to the period from 2002 through 2011 and were taken from the World Bank (http://databank.worldbank.org, accessed April 20, 2016). The intention was to cover a decade-long period with the most recent data available. When this research was started, the last available data for $\mathrm{CO} 2$ emissions per capita were for the year 2011. They are also meant to reflect significant differences in population size among OECD countries and the resulting large disparities in most of the socio-economic indicators. Therefore, wherever available, data values expressed in per capita terms or as a proportion or a rate were selected. In this way, population is incorporated into other variables. Therefore, even though it is the most important dynamic variable that affects all the other selected indicators, and is even inherent to them, it is not selected as a separate model variable. This approach also eliminates the influence of the part of discrepancy between indicators of socio-economic development of the OECD countries resulting from significant differences in terms of population. Since the number of scientific and technical 
journal articles was not available about population size, the data were not taken in their original form but were calculated per 100,000 inhabitants. This way, changes in population size during the selected period are also considered. These data adaptations offer more reliable comparisons and lead to easier results' interpretations. Table 1 provides summary statistics for the adjusted data of each variable used in the analysis, aggregated across countries and over time.

The selected indicators will be synthesized into a unique performance measure which merges separate indicators into one single statistic. Out of these eight indicators, we specified inflation as input, because if a country can control inflation, it is an indicator of that country's superior performance. Moreover, a stable and low cost of living, reflected in a low inflation, is arguably the most significant macroeconomic indicator for any society. All the remaining seven indicators were considered as outputs, two of which are undesirable (unemployment rate and $\mathrm{CO} 2$ emissions). Since the variables for which smaller (larger) amounts are preferable are commonly considered inputs (outputs), these undesirable outputs were converted to desirable by taking their reciprocals. This preserves the relationships between the data enabling the evaluation of macroeconomic performance regarding the country's ability to minimize the inflation, the harmful effects of air pollution on the environment, and to maximize the provision of six socioeconomic services.

Table 1

Data Summary Statistics, 2002-2011

\begin{tabular}{|c|c|c|c|c|c|c|c|c|}
\hline $\mathrm{V}$ & $\mathrm{a}$ & $\mathrm{e}$ & Mean & Median & SD & Min. & Max. & $\mathrm{CV}$ \\
\hline Input & & Inflation rate & 2.8 & 2.4 & 3.3 & -5.2 & 37.4 & 117.9 \\
\hline \multirow[t]{7}{*}{ Outputs } & \multirow[t]{5}{*}{ Desirable } & $\begin{array}{l}\text { Real per capita GDP } \\
\text { (constant } 2005 \text { US\$) }\end{array}$ & $34,293.5$ & $35,861.9$ & $17,563.4$ & $5,942.7$ & $87,772.7$ & 51.2 \\
\hline & & Exports/imports cover ratio & 103.0 & 103.9 & 17.3 & 62.5 & 161.4 & 16.8 \\
\hline & & $\begin{array}{l}\text { Scientific and technical journal } \\
\text { articles }\end{array}$ & 105.9 & 105.6 & 49.8 & 5.3 & 246.2 & 47.0 \\
\hline & & $\begin{array}{l}\text { Public health expenditure } \\
\text { (\% of total health expenditure) }\end{array}$ & 72.9 & 75.0 & 10.8 & 42.2 & 90.5 & 14.8 \\
\hline & & $\begin{array}{l}\text { Seats held by women in national } \\
\text { parliaments }\end{array}$ & 24.6 & 23.0 & 10.5 & 4.0 & 47.0 & 42.7 \\
\hline & \multirow[b]{2}{*}{ Undesirable } & Unemployment rate & 7.1 & 6.4 & 3.5 & 2.3 & 21.7 & 49.3 \\
\hline & & $\begin{array}{l}\mathrm{CO} 2 \text { emissions } \\
\text { (metric tons per capita) }\end{array}$ & 9.4 & 8.6 & 4.3 & 3.2 & 24.8 & 45.7 \\
\hline
\end{tabular}

Source: Author's calculations based on data from the World Bank SD - standard deviation; CV - coefficient of variation.

\section{Methodology}

DEA is a linear programming based methodology that, upon data on inputs and outputs of the observed entities/decision-making units (DMUs), designs a frontier that consists of the DMUs that have demonstrated best practice, and at the same time envelops all the other DMUs. After that, the relative performance of DMUs is assessed in terms of their distance from this empirically constructed frontier. Since its development and introduction by Charnes, Cooper \& Rhodes (1978), DEA has become a principal method in a whole spectrum of efficiency and productivity comparisons among mutually similar entities such as companies or countries. Up until the year 2009, the field has accumulated approximately 4500 papers in ISI Web of Science database (Liu et al., 2013). A respectable number of models was developed, that differ in the choice of returnsto-scale and orientation and thus in the resulting type of efficiency. There are also numerous model extensions, one of which is used in this paper.

The most often used models in research articles concerning DEA applications are Charnes-Cooper-Rhodes (Charnes et al., 1978) and Banker-Charnes-Cooper (Banker et al., 1984), named CCR and BCC after the initials of their authors. The CCR model assumes that the production function exhibits constant returns-to-scale. To permit variable returns-to-scale, the BCC model adds the additional constraint. Each of these models offers a choice of model orientation by the specification of the performance improvement direction towards inputs or toward outputs.
The aim in the first case is at decreasing input levels (input-oriented model), and in the second case at increasing output amounts (output-oriented model). The returns-to-scale selection affects the production possibility set and therefore depends on the characteristics of the production frontiers of the process to be analysed. The choice of model orientation depends on whether management is more interested (or has more influence) in improving input or output levels.

The possibility of removing inefficiencies due to scale seems not to be likely because of uncontrollable changes in the macroeconomic environment of each country. For this reason, when it comes to assessing potential improvements, variable returns-to-scale has been assumed. For the reasons given earlier, all the selected variables, except for inflation rate, are considered outputs. The next logical step is, therefore, the choice of output-oriented model that provides the exact extent to which outputs can be improved without worsening the inputs.

Since the period under study is divided into ten subperiods, an appropriate overview of the obtained results over time should be enabled. This will be provided by the window analysis where each window, as the period within which the comparisons are performed, may cover from one to ten years, depending on its length. With this dynamic extension to the basic DEA models, the relative efficiency of a country can be assessed not only in relation to other countries within the same subperiod but also with regard to other countries' outcomes, including its own, from another sub-period. However, based on the purpose of the analysis, the length of the window, from which the number of windows is derived, must be determined. For example, if a 
window length of eight years is chosen, there are three windows (2002-2009, 2003-2010 and 2004-2011). In this way, the beginning and ending years are not tested as frequently as the others, which makes the analysis in a way unbalanced. Therefore, the equal treatment of all years from the observed period is only possible in the cases with minimum and maximum window length. In the first case, there are ten one-year windows and in the second case, one ten-year window. To meet the aim of this research, at the same time bridging mentioned deficiency, precisely these two cases will be considered. Moreover, the eight selected indicators will be divided into four macroeconomic performance indicators of OECD's Magic Diamond (real per capita GDP, inflation rate, unemployment rate and exports/imports cover ratio - hereafter referred to as 'economic indicators') to accomplish macroeconomic analysis, and four social, institutional and environmental indicators (public health expenditure, scientific and technical journal articles, seats held by women in national parliaments and $\mathrm{CO} 2$ emissions - hereafter referred to as 'social indicators') to analyse specific aspects of quality of life. The economic indicators will be considered separately as well as in combination with the social indicators. In this way, four models will be obtained. These models will be hereafter referred to as Model 1, Model 2, Model 3 and Model 4, respectively (Figure 1). The following short description of the method employed is based on Cooper et al. (2006, pp. 87-89). Consider that we are interested in

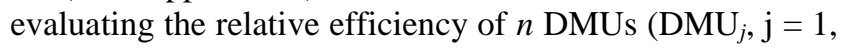
$2, \ldots, n)$, each of which uses $m$ inputs to produce $s$ outputs.

\begin{tabular}{|c|c|c|}
\hline & $\begin{array}{l}\text { Window length of } 1 \text { year } \\
\text { (10 sets of } 30 \text { entities) }\end{array}$ & $\begin{array}{l}\text { Window length of } 10 \text { years } \\
\text { ( } 1 \text { set of } 300 \text { entities) }\end{array}$ \\
\hline 4 indicators & Model 1 & Model 2 \\
\hline 8 indicators & Model 3 & Model 4 \\
\hline
\end{tabular}

Figure 1. DEA models for performance efficiency evaluation of OECD countries Source: Author's

The output-oriented BCC model evaluates the efficiency of $\mathrm{DMU}_{o}$ by solving the following (envelopment form) linear program:

$$
\begin{aligned}
\max _{\eta_{B}, \mu} \eta_{B} & \\
\text { subject to } & X \mu \leq x_{o} \\
& \eta_{B} y_{o}-Y \mu \leq 0 \\
& e \mu=1 \\
& \mu \geq 0
\end{aligned}
$$

where $X=\left(x_{j}\right) \in \mathrm{R}_{m \times n}$ and $Y=\left(y_{j}\right) \in \mathrm{R}_{s \times n}$ are the input and output data matrices, respectively, while $\mu \in \mathrm{R}_{n}$, and $e$ is the $n$-dimensional row vector whose components are all equal to 1 . Conditions (1), (2) and (4) consist of $m, s$ and $n$ constraints, respectively. In the case of the OECD countries, $n$ is $30, m$ is 1 and $s$ is 3 or 7 (depending on the model choice). Vector $\mu$ shows the proportions in which efficient DMUs contribute to the projection of inefficient $\mathrm{DMU}_{o}$ onto efficient frontier. The optimal objective value $\eta_{B}^{*}$ is a scalar that equals the reciprocal of the efficiency score, and for inefficient $\mathrm{DMU}_{0}$ also represents the output enlargement rate $\left(\eta_{B}^{*} \geq 1\right)$.

This first phase maximizes $\eta_{B}$ and the first two constraints of the associated linear program indicate that $(X \mu, Y \mu)$ outperforms $\left(x_{o}, \eta_{B}^{*} y_{o}\right)$ when $\eta_{B}^{*}>1$. In this context, the input surpluses and the output shortages are calculated respectively by the formulas

$$
t^{-}=x_{o}-X \mu, \quad t^{+}=Y \mu-\eta_{B} y_{o},
$$

with $t^{-} \in \mathrm{R}^{m}, t^{-} \geq 0$ and $t^{+} \in \mathrm{R}^{s}, t^{+} \geq 0$ for any feasible solution $\left(\eta_{B}, \mu\right)$.

In the second phase, possible remaining input surpluses and output shortages will be discovered by maximizing their sum, keeping $\eta_{B}=\eta_{B}^{*}$.

Definition 1 (BCC-Efficiency):

If an optimal solution $\left(\eta_{B}^{*}, \mu^{*}, t^{-*}, t^{+*}\right)$ obtained in this two-phase process satisfies $\eta_{B}^{*}=1$ and has no slack $\left(t^{-*}=\right.$ $\left.0, t^{+*}=0\right)$, then the $\mathrm{DMU}_{\mathrm{o}}$ is called BCC-efficient, otherwise it is BCC-inefficient.
Definition 2 (Reference Set):

For a BCC-inefficient $\mathrm{DMU}_{\mathrm{o}}$, its reference set $E_{o}$ is defined based on an optimal solution $\mu^{*}$ by

$$
E_{o}=\left\{j \mid \mu_{j}^{*}>0\right\} \quad(j \in\{1,2, \ldots, n\}) .
$$

Any of the eventually multiple optimal solutions can be chosen to find that

$$
\begin{aligned}
& x_{o}=\sum_{j \epsilon E_{o}} x_{j} \mu_{j}^{*}+t^{-*}, \\
& \eta^{*} y_{o}=\sum_{j \epsilon E_{o}} y_{j} \mu_{j}^{*}-t^{+*} .
\end{aligned}
$$

Thus, the formula for improvement via the $B C C$ projection onto the efficient frontier is

$$
\begin{aligned}
& \hat{x}_{o}=x_{o}-t^{-*}, \\
& \hat{y}_{o}=\eta^{*} y_{o}+t^{+*} .
\end{aligned}
$$

The window analysis model is constructed in the same manner as the basic model, with the difference in the number of the observed entities.

\section{Empirical Application of the Model and Analysis of Results}

The relative efficiency scores of the thirty OECD countries are calculated by DEA-Solver Software from the Saitech Company.

The first model (Model 1) uses ten one-year windows. This way, each country's performance in a certain year is compared only with the performances of all other countries in the same year, which is performed separately for each year. Since each country is regarded as an individual DMU for each year, the efficiency in this model is analysed within ten sets, each of which consists of thirty entities. The analysis is based on four macroeconomic indicators of OECD's Magic Diamond. The relative efficiency scores, provided in Table 2 for each country in each year, facilitate the comparison of all countries' performances in the same 
year as well as the comparison of one country's efficiency scores in all years. The highest average efficiency score (0.849) was achieved in 2011, and the lowest (0.756) in 2002. At the same time, the number of efficient countries was highest (7) for the years 2006 and 2010, and lowest (2) for the year 2009. The only consistently efficient countries were Luxembourg and Norway, while as many as 20 countries showed persistent inefficiency. While some countries remained consistently low (e.g. Greece and Turkey), a few fluctuated between high and low efficiency rating and vice versa (e.g. Poland and Mexico). Except for the final year of study, Greece was a consistently least efficient country with the average efficiency score of 0.509521 . The average efficiency score (for all countries over the entire period) of 0.808942 indicates that on average the countries had $19.1 \%((1-0.808942) * 100)$ inefficiency.

The standard deviations are obviously much smaller when observing the same country in different years than when observing various countries in the same year. This gives evidence of rather balanced performance over time on country level but significant disparities among countries. These disparities are specifically confirmed by significant differences between minimum and maximum (1) efficiency scores.

Table 2

Efficiency Scores - Model 1 (4 Indicators, 10 Windows)

\begin{tabular}{|c|c|c|c|c|c|c|c|c|c|c|c|c|}
\hline \multirow{2}{*}{ Country } & \multicolumn{10}{|l|}{ Year } & \multirow{2}{*}{$\begin{array}{l}\text { Average } \\
\text { per } \\
\text { country }\end{array}$} & \multirow{2}{*}{$\begin{array}{l}\text { Std. } \\
\text { dev. }\end{array}$} \\
\hline & 2002 & 2003 & 2004 & 2005 & 2006 & 2007 & 2008 & 2009 & 2010 & 2011 & & \\
\hline Australia & 0.676 & 0.675 & 0.715 & 0.742 & 0.708 & 0.639 & 0.690 & 0.715 & 0.820 & 0.738 & 0.711924 & 0.049 \\
\hline Austria & 0.799 & 0.905 & 0.857 & 0.839 & 0.859 & 0.789 & 0.904 & 0.763 & 0.960 & 0.894 & 0.856894 & 0.061 \\
\hline Belgium & 0.733 & 0.766 & 0.817 & 0.829 & 0.825 & 0.773 & 0.785 & 0.736 & 0.783 & 0.818 & 0.786417 & 0.035 \\
\hline Canada & 0.756 & 0.757 & 0.831 & 0.847 & 0.829 & 0.736 & 0.781 & 0.676 & 0.710 & 0.744 & 0.766741 & 0.056 \\
\hline Czech Republic & 0.657 & 0.721 & 0.726 & 0.884 & 0.839 & 0.717 & 0.835 & 0.762 & 0.903 & 0.953 & 0.799748 & 0.097 \\
\hline Denmark & 0.805 & 0.858 & 0.878 & 0.900 & 0.979 & 0.762 & 0.878 & 0.784 & 0.857 & 0.949 & 0.864881 & 0.069 \\
\hline Finland & 0.875 & 0.937 & 0.951 & 0.914 & 0.932 & 0.789 & 0.824 & 0.753 & 0.824 & 0.779 & 0.857818 & 0.073 \\
\hline France & 0.718 & 0.743 & 0.790 & 0.782 & 0.768 & 0.679 & 0.726 & 0.673 & 0.727 & 0.775 & 0.738240 & 0.041 \\
\hline Germany & 0.781 & 0.830 & 0.914 & 0.962 & 0.976 & 0.891 & 0.936 & 0.818 & 0.896 & 0.944 & 0.894754 & 0.066 \\
\hline Greece & 0.450 & 0.437 & 0.522 & 0.565 & 0.498 & 0.444 & 0.476 & 0.470 & 0.562 & 0.672 & 0.509521 & 0.073 \\
\hline Hungary & 0.658 & 0.683 & 0.682 & 0.752 & 0.695 & 0.663 & 0.680 & 0.927 & 0.926 & 0.867 & 0.753363 & 0.110 \\
\hline Iceland & 0.834 & 1 & 1 & 1 & 1 & 1 & 0.883 & 0.870 & 0.890 & 0.916 & 0.939301 & 0.067 \\
\hline Ireland & 0.860 & 0.900 & 0.943 & 0.964 & 0.928 & 0.897 & 1 & 0.832 & 1 & 0.987 & 0.931026 & 0.059 \\
\hline Italy & 0.699 & 0.694 & 0.769 & 0.788 & 0.767 & 0.711 & 0.750 & 0.693 & 0.744 & 0.782 & 0.739655 & 0.037 \\
\hline Japan & 0.771 & 1 & 1 & 1 & 1 & 1 & 1 & 0.735 & 1 & 1 & 0.950618 & 0.104 \\
\hline Korea & 0.837 & 0.960 & 0.989 & 1 & 1 & 0.834 & 0.871 & 0.889 & 1 & 1 & 0.938038 & 0.072 \\
\hline Luxembourg & 1 & 1 & 1 & 1 & 1 & 1 & 1 & 1 & 1 & 1 & 1 & 0 \\
\hline Mexico & 0.897 & 1 & 0.912 & 0.899 & 0.996 & 0.722 & 0.773 & 0.675 & 0.727 & 0.693 & 0.829298 & 0.125 \\
\hline Netherlands & 1 & 1 & 0.922 & 0.928 & 0.939 & 0.858 & 1 & 0.941 & 0.963 & 0.988 & 0.953927 & 0.046 \\
\hline New Zealand & 0.744 & 0.829 & 0.907 & 0.914 & 0.869 & 0.695 & 0.804 & 0.776 & 0.802 & 0.857 & 0.819603 & 0.070 \\
\hline Norway & 1 & 1 & 1 & 1 & 1 & 1 & 1 & 1 & 1 & 1 & 1 & 0 \\
\hline Poland & 0.604 & 0.696 & 0.660 & 0.752 & 1 & 0.896 & 0.986 & 0.959 & 1 & 0.743 & 0.829735 & 0.154 \\
\hline Portugal & 0.587 & 0.613 & 0.616 & 0.573 & 0.581 & 0.558 & 0.600 & 0.567 & 0.627 & 0.808 & 0.612971 & 0.072 \\
\hline Slovak Republic & 0.601 & 0.659 & 0.653 & 0.733 & 0.675 & 0.775 & 0.736 & 0.696 & 0.748 & 0.816 & 0.709215 & 0.064 \\
\hline Spain & 0.628 & 0.623 & 0.624 & 0.610 & 0.585 & 0.560 & 0.647 & 0.679 & 0.741 & 0.877 & 0.657443 & 0.092 \\
\hline Sweden & 0.795 & 0.844 & 0.975 & 0.986 & 0.962 & 0.817 & 0.862 & 0.818 & 0.889 & 0.931 & 0.887988 & 0.071 \\
\hline Switzerland & 1 & 0.989 & 1 & 1 & 1 & 0.894 & 1 & 0.834 & 1 & 1 & 0.971761 & 0.059 \\
\hline Turkey & 0.722 & 0.651 & 0.611 & 0.573 & 0.510 & 0.560 & 0.534 & 0.680 & 0.566 & 0.508 & 0.591452 & 0.073 \\
\hline United Kingdom & 0.644 & 0.756 & 0.790 & 0.788 & 0.728 & 0.632 & 0.693 & 0.653 & 0.690 & 0.770 & 0.714365 & 0.060 \\
\hline United States & 0.559 & 0.629 & 0.669 & 0.673 & 0.803 & 0.606 & 0.670 & 0.601 & 0.646 & 0.660 & 0.651568 & 0.065 \\
\hline Average per year & 0.756 & 0.805 & 0.824 & 0.840 & 0.842 & 0.763 & 0.811 & 0.766 & 0.833 & 0.849 & 0.808942 & 0.067 \\
\hline Std. dev. & 0.140 & 0.153 & 0.146 & 0.141 & 0.159 & 0.147 & 0.148 & 0.127 & 0.139 & 0.126 & 0.128413 & 0.031 \\
\hline Minimum score & 0.450 & 0.437 & 0.522 & 0.565 & 0.498 & 0.444 & 0.476 & 0.470 & 0.562 & 0.508 & 0.509521 & 0 \\
\hline No. $(\%)$ of efficient & 4 & 6 & 5 & 6 & 7 & 4 & 6 & 2 & 7 & 5 & 2 & \\
\hline countries & $13 \%$ & $20 \%$ & $17 \%$ & $20 \%$ & $23 \%$ & $13 \%$ & $20 \%$ & $7 \%$ & $23 \%$ & $17 \%$ & $7 \%$ & \\
\hline
\end{tabular}

Source: Author's calculations based on data from the World Bank

Because the DEA window models offer valuable information on relative efficiency trends, their relevance is beyond doubt. However, these models do not provide indispensable information on inefficiency sources and proposed improvements. Getting this information involves running the basic BCC model ten times - once for each year's data for all thirty observed countries. The efficiency levels for these ten analyses are identical to those shown in Table 2. The input excesses and output shortfalls, i.e. the differences between empirical and projected values (or vice versa) in each input and output, were calculated taking into account executed scaling of original data for the undesirable output. They were then averaged per country and are expressed as percentages of their respective initial values in Table 3. They represent needed improvements that can be achieved using the previously explained two-phase procedure. For example, the mean efficiency score in 2011 was 0.849 , implying that on average the countries were 15.1 $\%$ inefficient. This entails that, on average, all output levels should be increased by $17.8 \%$, without influencing the initial input levels, to remove radial inefficiency (the first phase). $(1 / 0.849-1)^{*} 100$ (as explained earlier, the reciprocal of the efficiency result is the optimal objective value for the output-oriented model). In the same year, however, the major output shortfall was in real per capita GDP, with the average required an increase of $147.4 \%$. This 
implies that the efficiency cannot be achieved only by increasing all outputs proportionally, but the countries should further augment output amounts and thus remove remaining inefficiencies (the second phase). It is intuitively understandable that largely demanded changes in input and output quantities indicate cross country divergence. The numbers in Table 3, therefore, confirm deep development disparities among OECD countries. Throughout the entire period, real per capita GDP had the strongest impact on the efficiency. The only exception was the year 2009, in which the inflation rate took the lead in influencing the efficiency. On the other side, the efficiency was least affected by the inflation rate, with the exceptions of the years 2002 and 2009 in which this was by the ratio of exports to imports. These two deviations can be explained by following reasons. 2002 is the year in which the highest standard deviation in inflation rates, as well as the greatest difference between their maximum and minimum values, was observed. At the same time, the two lowest values for the inflation rate were recorded in 2009.

Table 3

Sources of Inefficiency - Model 1 (4 Indicators, 10 Windows)

\begin{tabular}{|c|c|c|c|c|c|c|c|c|c|c|c|c|}
\hline \multirow{2}{*}{$\mathrm{V}$} & \multirow{2}{*}{$\mathrm{r}$} & \multirow{2}{*}{$\mathrm{b}$} & \multicolumn{10}{|c|}{ Input and output improvements (\%) } \\
\hline & & & 2002 & 2003 & 2004 & 2005 & 2006 & 2007 & 2008 & 2009 & 2010 & 2011 \\
\hline \multicolumn{2}{|l|}{ Input } & $\begin{array}{l}\text { Inflation } \\
\text { rate }\end{array}$ & -138.7 & -8.1 & -4.6 & 0 & -0.2 & -9.0 & -0.8 & -382.5 & -1.7 & -0.8 \\
\hline \multirow{3}{*}{ Outputs } & \multirow[b]{2}{*}{ Desirable } & $\begin{array}{l}\text { Real per capita } \\
\text { GDP }\end{array}$ & 211.5 & 144.6 & 173.0 & 123.6 & 79.1 & 178.3 & 147.6 & 191.9 & 64.4 & 147.4 \\
\hline & & $\begin{array}{l}\text { Exports/imports } \\
\text { cover ratio }\end{array}$ & 37.7 & 30.0 & 26.3 & 23.9 & 26.1 & 38.6 & 31.3 & 35.6 & 24.4 & 21.4 \\
\hline & Undesirable & $\begin{array}{l}\text { Unemployment } \\
\text { rate }\end{array}$ & -48.0 & -40.6 & -41.2 & -39.8 & -32.4 & -54.7 & -38.9 & -58.7 & -24.7 & -54.0 \\
\hline
\end{tabular}

Source: Author's calculations based on data from the World Bank

Both of these situations result with the efficient frontier that is, considering this variable, more distant from inefficient countries, and is therefore more difficult to attain. The fact that the average required reduction in the inflation rate in both cases surpasses $100 \%$ means that the majority of inefficient countries need to reduce the rate of inflation to negative levels. Since the effect of negative inflation rates is questionable, and is not the subject of this paper, we do not add further comments here. These results reveal two interesting facts about the inflation rate. There are many factors that affect inflation but are not the subject of this research. Firstly, it is the only indicator both among the most and the least influential indicators. Secondly, it is the only indicator that does not need to be improved in one year (2005) of the observed period. This is the consequence of the significant cross-sample dispersion of inflation rates, which is confirmed by the coefficient of variation that has by far the highest value $(117.9 \%)$ among all the indicators used to assess the relative efficiency of the OECD countries (see Table 1).

Since, in this model, all years were considered separately, the best efficiency result of a given country in a particular year does not necessarily mean its highest performance during the entire examined period. It means only that its performance compared with other countries for that given year was better than its performance compared with other countries in the remaining years. Accordingly, this model is not suitable for direct comparison across calendar years for each country since the comparison basis is different for each year. Consequently, it seems meaningful to extend the comparison to include all countries in all years, which leads to the second model (Model 2). In this model, the efficiency evaluation is based on the same four indicators, but one ten-year window is used. This way, each country's performance in each year is compared with the performances of all other countries in all years. The efficiency in this model is therefore analysed within one set of 300 entities. This makes the essential difference between this and the previous model. The relative efficiency results of the Model 2 throughout the entire period are presented in Table 4. As evident, none of the countries has been able to accomplish continuous efficiency. Out of 300 observed entities, only eight were relatively efficient. Norway was efficient in five years, Luxembourg in two years and Iceland in one year, while the rest of 27 countries showed no efficiency. No country has shown continuous efficiency growth, while Finland was the only country with continuous efficiency decline. The number of efficient countries was highest (3) for the year 2007, while in the years 2003, 2004, 2005, 2010 and 2011 no country was efficient. The highest average efficiency score (0.719) was achieved in 2002, and the lowest (0.688) in 2011. It should be emphasized this is an entirely opposite result from that of the previous model. The reason for this turn may be attributed to the different window length as explained earlier.

The lowest of 300 efficiency scores (0.404) was obtained by Greece in 2003. Like the previous model, the lowest average efficiency score was recorded by Greece (0.446643), while the highest two were achieved by Norway (0.976003) and Luxembourg (0.960589). These numbers again testify to the differences among OECD members, which are here even deeper than in the previous model. Compared to a year earlier, the most significant efficiency decrease was recorded by Mexico in $2006(-0.274)$. At the same time, the highest efficiency improvement was achieved by Japan in $2010(+0.265)$. Among other countries, Luxembourg makes an interesting example since it was efficient throughout the entire period when years were observed separately, and only in two years when years were mutually compared. This is because no country was more efficient than Luxembourg in, for example, 2011, but some of them, including Luxembourg itself in 2002, 2006, 2007, 2008, 2009 and 2010, were more efficient in some of the remaining years. Expectedly, as a conclusion, some similarities but also distinct differences are indicated by the results generated by Models 1 and 2. The inefficiency 
sources in the form of the demanded input and output improvements averaged over the observed period are given in Table 5. In this model, the situation regarding the indicators' influence on efficiency levels is much clearer than in the previous model. Thus, the real per capita GDP again had the greatest impact on inefficiency, but this time with no exception and even stronger than in the previous model. The efficiency was again least affected by the inflation rate, here also without exception. The fact that, compared to the previous model, the differences among OECD countries deepened, again is a direct consequence of different window length. Considerably greater average impact of outputs rather than of input on the efficiency is predetermined by selection of the model orientation. The third model (Model 3), as well as the first one, uses ten oneyear windows but bases the efficiency assessment on the complete set of eight selected indicators.

Efficiency Scores - Model 2 (4 Indicators, 1 Window)

\begin{tabular}{|c|c|c|c|c|c|c|c|c|c|c|c|c|}
\hline \multirow{2}{*}{ Country } & \multicolumn{10}{|l|}{ Year } & \multirow{2}{*}{$\begin{array}{l}\text { Average } \\
\text { per } \\
\text { country } \\
\end{array}$} & \multirow{2}{*}{$\begin{array}{l}\text { Std. } \\
\text { dev. }\end{array}$} \\
\hline & 2002 & 2003 & 2004 & 2005 & 2006 & 2007 & 2008 & 2009 & 2010 & 2011 & & \\
\hline Australia & 0.650 & 0.587 & 0.569 & 0.576 & 0.599 & 0.613 & 0.600 & 0.642 & 0.635 & 0.666 & 0.613602 & 0.033 \\
\hline Austria & 0.735 & 0.715 & 0.703 & 0.697 & 0.709 & 0.720 & 0.737 & 0.707 & 0.718 & 0.706 & 0.714756 & 0.013 \\
\hline Belgium & 0.712 & 0.709 & 0.702 & 0.688 & 0.687 & 0.688 & 0.659 & 0.684 & 0.670 & 0.659 & 0.685785 & 0.019 \\
\hline Canada & 0.738 & 0.722 & 0.736 & 0.725 & 0.705 & 0.691 & 0.680 & 0.646 & 0.612 & 0.623 & 0.687651 & 0.047 \\
\hline Czech Republic & 0.633 & 0.643 & 0.653 & 0.691 & 0.692 & 0.673 & 0.692 & 0.698 & 0.708 & 0.706 & 0.678821 & 0.027 \\
\hline Denmark & 0.765 & 0.778 & 0.748 & 0.739 & 0.737 & 0.728 & 0.735 & 0.732 & 0.739 & 0.740 & 0.744251 & 0.016 \\
\hline Finland & 0.855 & 0.805 & 0.789 & 0.732 & 0.732 & 0.730 & 0.707 & 0.694 & 0.687 & 0.639 & 0.736954 & 0.064 \\
\hline France & 0.696 & 0.685 & 0.673 & 0.646 & 0.635 & 0.622 & 0.615 & 0.629 & 0.615 & 0.604 & 0.641829 & 0.032 \\
\hline Germany & 0.761 & 0.744 & 0.768 & 0.764 & 0.762 & 0.776 & 0.767 & 0.754 & 0.754 & 0.741 & 0.759080 & 0.011 \\
\hline Greece & 0.431 & 0.404 & 0.460 & 0.470 & 0.433 & 0.418 & 0.422 & 0.430 & 0.477 & 0.522 & 0.446643 & 0.035 \\
\hline Hungary & 0.601 & 0.595 & 0.599 & 0.630 & 0.623 & 0.611 & 0.603 & 0.840 & 0.844 & 0.703 & 0.664853 & 0.098 \\
\hline Iceland & 0.752 & 0.774 & 0.797 & 0.905 & 0.822 & 1 & 0.842 & 0.802 & 0.804 & 0.795 & 0.829301 & 0.073 \\
\hline Ireland & 0.791 & 0.798 & 0.795 & 0.764 & 0.753 & 0.767 & 0.773 & 0.820 & 0.807 & 0.796 & 0.786399 & 0.021 \\
\hline Italy & 0.669 & 0.663 & 0.669 & 0.650 & 0.634 & 0.643 & 0.636 & 0.638 & 0.618 & 0.621 & 0.643962 & 0.018 \\
\hline Japan & 0.771 & 0.788 & 0.790 & 0.756 & 0.747 & 0.759 & 0.709 & 0.696 & 0.740 & 0.659 & 0.741578 & 0.042 \\
\hline Korea & 0.754 & 0.724 & 0.747 & 0.738 & 0.792 & 0.786 & 0.773 & 0.746 & 0.724 & 0.759 & 0.754448 & 0.024 \\
\hline Luxembourg & 1 & 0.926 & 0.928 & 0.934 & 0.962 & 1 & 0.976 & 0.953 & 0.966 & 0.961 & 0.960589 & 0.027 \\
\hline Mexico & 0.828 & 0.805 & 0.671 & 0.705 & 0.762 & 0.722 & 0.702 & 0.620 & 0.623 & 0.616 & 0.705405 & 0.076 \\
\hline Netherlands & 0.932 & 0.766 & 0.756 & 0.756 & 0.763 & 0.801 & 0.894 & 0.791 & 0.755 & 0.757 & 0.797238 & 0.064 \\
\hline New Zealand & 0.731 & 0.701 & 0.681 & 0.674 & 0.677 & 0.681 & 0.669 & 0.708 & 0.702 & 0.691 & 0.691604 & 0.019 \\
\hline Norway & 1 & 0.960 & 0.951 & 0.983 & 1 & 1 & 1 & 1 & 0.923 & 0.943 & 0.976003 & 0.029 \\
\hline Poland & 0.584 & 0.614 & 0.598 & 0.633 & 0.905 & 0.837 & 0.853 & 0.869 & 0.914 & 0.619 & 0.742479 & 0.142 \\
\hline Portugal & 0.517 & 0.520 & 0.505 & 0.483 & 0.507 & 0.522 & 0.500 & 0.526 & 0.530 & 0.593 & 0.520316 & 0.029 \\
\hline Slovak Republic & 0.572 & 0.618 & 0.611 & 0.614 & 0.620 & 0.651 & 0.628 & 0.658 & 0.651 & 0.650 & 0.627305 & 0.026 \\
\hline Spain & 0.598 & 0.591 & 0.560 & 0.535 & 0.521 & 0.525 & 0.545 & 0.634 & 0.633 & 0.659 & 0.580079 & 0.050 \\
\hline Sweden & 0.773 & 0.774 & 0.805 & 0.785 & 0.779 & 0.760 & 0.742 & 0.751 & 0.750 & 0.733 & 0.765001 & 0.022 \\
\hline Switzerland & 0.930 & 0.780 & 0.810 & 0.791 & 0.806 & 0.838 & 0.838 & 0.805 & 0.831 & 0.815 & 0.824256 & 0.042 \\
\hline Turkey & 0.662 & 0.594 & 0.558 & 0.542 & 0.510 & 0.513 & 0.523 & 0.609 & 0.503 & 0.457 & 0.546940 & 0.060 \\
\hline United Kingdom & 0.594 & 0.602 & 0.601 & 0.603 & 0.602 & 0.604 & 0.600 & 0.601 & 0.595 & 0.622 & 0.602402 & 0.008 \\
\hline United States & 0.530 & 0.524 & 0.539 & 0.559 & 0.582 & 0.585 & 0.556 & 0.577 & 0.574 & 0.574 & 0.559991 & 0.022 \\
\hline Average per year & 0.719 & 0.697 & 0.692 & 0.692 & 0.702 & 0.709 & 0.699 & 0.709 & 0.703 & 0.688 & 0.700984 & 0.040 \\
\hline Std. dev. & 0.139 & 0.120 & 0.118 & 0.122 & 0.130 & 0.140 & 0.135 & 0.120 & 0.121 & 0.108 & 0.116813 & 0.029 \\
\hline Minimum score & 0.431 & 0.404 & 0.460 & 0.470 & 0.433 & 0.418 & 0.422 & 0.430 & 0.477 & 0.457 & 0.446643 & 0.008 \\
\hline Maximum score & 1 & 0.960 & 0.951 & 0.983 & 1 & 1 & 1 & 1 & 0.966 & 0.961 & 0.976003 & 0.142 \\
\hline No. (\%) of efficient & 2 & 0 & 0 & 0 & 1 & 3 & 1 & 1 & 0 & 0 & 0 & \\
\hline countries & $7 \%$ & $0 \%$ & $0 \%$ & $0 \%$ & $3 \%$ & $10 \%$ & $3 \%$ & $3 \%$ & $0 \%$ & $0 \%$ & $0 \%$ & \\
\hline
\end{tabular}

Source: Author's calculations based on data from the World Bank

The number of indicators makes the only difference between two models, thus turning the Model 3 into a kind of the Model 1 extension.

Table 5

Sources of Inefficiency - Model 2 (4 Indicators, 1 Window)

\begin{tabular}{|c|c|c|c|c|c|c|c|c|c|c|c|c|c|}
\hline \multirow{2}{*}{ V } & \multirow{2}{*}{$\mathrm{r}$} & \multirow{2}{*}{ a } & \multirow{2}{*}{1} & \multicolumn{10}{|c|}{ Input and output improvements (\%) } \\
\hline & & & & 2002 & 2003 & 2004 & 2005 & 2006 & 2007 & 2008 & 2009 & 2010 & 2011 \\
\hline Input & & & & -5.3 & -3.4 & -4.3 & -4.4 & -7.8 & -2.8 & -7.7 & -0.4 & -0.8 & -1.6 \\
\hline \multirow{3}{*}{$\stackrel{\Xi}{\Xi} \cong$} & \multirow{2}{*}{ Desirable } & \multicolumn{2}{|c|}{ Real per capita GDP } & 219.3 & 213.7 & 203.7 & 191.8 & 181.3 & 172.8 & 172.6 & 180.1 & 172.3 & 168.6 \\
\hline & & \multicolumn{2}{|c|}{ Exports/imports cover ratio } & 44.4 & 48.1 & 48.7 & 49.4 & 49.2 & 46.8 & 48.4 & 45.2 & 46.4 & 48.9 \\
\hline & Undesirable & Unemp & yment rate & -50.3 & -51.0 & -52.1 & -50.4 & -46.9 & -42.7 & -43.3 & -53.8 & -56.2 & -56.2 \\
\hline
\end{tabular}

Source: Author's calculations based on data from the World Bank 
Table 6 presents the relative efficiency scores of the Model 3. Although the comparisons between the results of the models with the same set of indicators and the different window length are interesting and bring valuable conclusions for this research, it is critical to compare the models with four indicators to those with eight indicators. This is meaningful if based on the same length windows. The reason for such a comparison lies in the fact that some countries which, according to macroeconomic indicators, belong among the most developed countries, often have serious problems related to various other domains such as healthcare, environment, and others.
The best average efficiency result $(0.962)$ was accomplished in 2010, and the worst (0.928) in 2002. The average total efficiency score of 0.941865 is evidently much higher than that in the Model 1 (0.808942). This can be explained by the fact that the major economies failed to perform so well on some of the social aspects relative to the countries with a poorer economic performance. A country example for each of the social indicators is given as follows. Luxembourg has the highest $\mathrm{CO} 2$ emissions per capita of all OECD countries. The share of public health expenditure is particularly low in Switzerland compared to the great majority of OECD countries.

Table 6

Efficiency Scores - Model 3 (8 Indicators, 10 Windows)

\begin{tabular}{|c|c|c|c|c|c|c|c|c|c|c|c|c|}
\hline \multirow{2}{*}{ Country } & \multicolumn{10}{|l|}{ Year } & \multirow{2}{*}{$\begin{array}{l}\text { Average } \\
\text { per } \\
\text { country }\end{array}$} & \multirow{2}{*}{$\begin{array}{l}\text { Std. } \\
\text { dev. }\end{array}$} \\
\hline & 2002 & 2003 & 2004 & 2005 & 2006 & 2007 & 2008 & 2009 & 2010 & 2011 & & \\
\hline Australia & 0.813 & 0.828 & 0.858 & 0.880 & 0.873 & 0.891 & 0.885 & 0.883 & 0.896 & 0.891 & 0.869835 & 0.028 \\
\hline Austria & 0.928 & 0.958 & 0.926 & 0.920 & 0.929 & 0.899 & 0.942 & 0.903 & 0.987 & 0.949 & 0.934099 & 0.026 \\
\hline Belgium & 0.869 & 0.888 & 0.913 & 0.919 & 0.905 & 0.907 & 0.918 & 0.903 & 0.917 & 0.896 & 0.903527 & 0.016 \\
\hline Canada & 0.841 & 0.847 & 0.859 & 0.869 & 0.869 & 0.869 & 0.878 & 0.867 & 0.857 & 0.831 & 0.858653 & 0.015 \\
\hline Czech Republic & 1 & 1 & 1 & 1 & 1 & 0.998 & 0.966 & 0.968 & 1 & 0.982 & 0.991494 & 0.014 \\
\hline Denmark & 1 & 1 & 1 & 1 & 1 & 1 & 1 & 1 & 1 & 1 & 1 & 0 \\
\hline Finland & 1 & 1 & 0.973 & 0.929 & 1 & 0.946 & 0.946 & 0.942 & 1 & 0.960 & 0.969503 & 0.029 \\
\hline France & 1 & 0.967 & 0.959 & 0.955 & 0.952 & 0.952 & 0.969 & 1 & 0.976 & 0.989 & 0.971978 & 0.019 \\
\hline Germany & 0.927 & 0.935 & 0.934 & 0.973 & 1 & 0.984 & 1 & 0.906 & 0.955 & 0.953 & 0.956710 & 0.032 \\
\hline Greece & 0.718 & 0.718 & 0.718 & 0.728 & 0.750 & 0.729 & 0.722 & 0.818 & 0.820 & 0.807 & 0.752809 & 0.044 \\
\hline Hungary & 0.928 & 0.913 & 0.900 & 0.898 & 0.898 & 0.881 & 0.889 & 1 & 1 & 0.955 & 0.926239 & 0.044 \\
\hline Iceland & 1 & 1 & 1 & 1 & 1 & 1 & 1 & 1 & 1 & 1 & 1 & 0 \\
\hline Ireland & 0.893 & 0.918 & 0.951 & 0.968 & 0.964 & 0.974 & 1 & 1 & 1 & 0.987 & 0.965549 & 0.036 \\
\hline Italy & 0.875 & 0.878 & 0.899 & 0.910 & 0.915 & 0.917 & 0.924 & 0.915 & 0.938 & 0.884 & 0.905541 & 0.021 \\
\hline Japan & 0.969 & 1 & 1 & 1 & 1 & 1 & 1 & 0.958 & 1 & 1 & 0.992749 & 0.016 \\
\hline Korea & 0.865 & 0.960 & 0.989 & 1 & 1 & 0.848 & 0.889 & 0.917 & 1 & 1 & 0.946837 & 0.062 \\
\hline Luxembourg & 1 & 1 & 1 & 1 & 1 & 1 & 1 & 1 & 1 & 1 & 1 & 0 \\
\hline Mexico & 1 & 1 & 1 & 1 & 1 & 1 & 1 & 1 & 1 & 1 & 1 & 0 \\
\hline Netherlands & 1 & 1 & 1 & 1 & 1 & 1 & 1 & 1 & 1 & 1 & 1 & 0 \\
\hline New Zealand & 0.927 & 0.941 & 0.964 & 0.977 & 1 & 0.982 & 0.990 & 0.979 & 0.989 & 0.973 & 0.972223 & 0.023 \\
\hline Norway & 1 & 1 & 1 & 1 & 1 & 1 & 1 & 1 & 1 & 1 & 1 & 0 \\
\hline Poland & 0.854 & 0.861 & 0.827 & 0.837 & 1 & 0.934 & 0.999 & 0.983 & 1 & 0.825 & 0.912086 & 0.078 \\
\hline Portugal & 0.915 & 0.913 & 0.907 & 0.879 & 0.898 & 0.887 & 1 & 0.956 & 1 & 1 & 0.935440 & 0.049 \\
\hline Slovak Republic & 1 & 1 & 0.892 & 0.899 & 0.832 & 0.929 & 0.836 & 0.949 & 0.862 & 0.865 & 0.906385 & 0.062 \\
\hline Spain & 0.852 & 0.852 & 0.872 & 0.875 & 0.878 & 0.877 & 0.908 & 0.917 & 1 & 1 & 0.903013 & 0.055 \\
\hline Sweden & 1 & 1 & 1 & 1 & 1 & 1 & 1 & 1 & 1 & 1 & 1 & 0 \\
\hline Switzerland & 1 & 1 & 1 & 1 & 1 & 1 & 1 & 1 & 1 & 1 & 1 & 0 \\
\hline Turkey & 1 & 1 & 1 & 1 & 1 & 1 & 1 & 1 & 1 & 1 & 1 & 0 \\
\hline United Kingdom & 0.947 & 0.955 & 0.972 & 0.959 & 0.967 & 0.958 & 0.965 & 0.978 & 0.987 & 0.974 & 0.966348 & 0.012 \\
\hline United States & 0.727 & 0.733 & 0.746 & 0.751 & 0.803 & 0.694 & 0.692 & 0.669 & 0.671 & 0.663 & 0.714929 & 0.045 \\
\hline Average per year & 0.928 & 0.935 & 0.935 & 0.938 & 0.948 & 0.935 & 0.944 & 0.947 & 0.962 & 0.946 & 0.941865 & 0.024 \\
\hline Std. dev. & 0.083 & 0.080 & 0.076 & 0.074 & 0.070 & 0.079 & 0.081 & 0.072 & 0.075 & 0.081 & 0.070860 & 0.022 \\
\hline Minimum score & 0.718 & 0.718 & 0.718 & 0.728 & 0.750 & 0.694 & 0.692 & 0.669 & 0.671 & 0.663 & 0.714929 & 0 \\
\hline No. (\%) of efficient & 13 & 13 & 11 & 12 & 16 & 10 & 13 & 12 & 18 & 13 & 9 & \\
\hline countries & $43 \%$ & $43 \%$ & $37 \%$ & $40 \%$ & $53 \%$ & $33 \%$ & $43 \%$ & $40 \%$ & $60 \%$ & $43 \%$ & $30 \%$ & \\
\hline
\end{tabular}

Source: Author's calculations based on data from the World Bank

Japan has comparatively low output of scientific and technical journal articles on a per capita basis. Ireland performs very poorly compared to the percentage of women in other national parliaments. The highest number of efficient countries (18) corresponds to 2010, while the lowest number (10) was shown in 2007. Regarding inefficient countries, only eight out of thirty countries have been persistently inefficient. At the same time, nine countries were efficient in all analysed years: Denmark, Iceland, Luxembourg, Mexico, Netherlands, Norway, Sweden, Switzerland and Turkey. While, according to the Model 1 efficiency scores, eight out of these nine countries performed above-average, Turkey scored well below the benchmark. This dramatic efficiency change is attributable solely to the fact that Turkey had the lowest per capita $\mathrm{CO} 2$ emissions during the first eight years of the period under investigation. There is no country whose efficiency deteriorated compared to the Model 1 and, as expected based on the previously mentioned, most significant shift in average efficiency score $(+0.408548)$ was accomplished by Turkey. For the opposite reason, the United States became on average the least efficient country (0.714929), with the lowest efficiency scores in the last five consecutive years. This could be interpreted as opposed to the fact that the United States is widely considered one of the strongest economies in the world. However, the discordance arises 
mainly from the selection of indicators. Namely, on one of the four economic indicators, and on even three of the four social indicators, the United States performs significantly worse than average. The mean values across the observed period for each of these indicators are as follows: exports/imports cover ratio - US 71.1/OECD 103.0, CO2 emissions - US 18.7/OECD 9.4, public health expenditure - US 45.5/OECD 72.9, seats held by woman in national parliaments - US 15.9/OECD 24.6.

Based on much higher minimum efficiency scores and on much smaller standard deviations within each year in the Model 3 than in the Model 1, it is concluded that disparities among countries are much more pronounced when the countries are compared based on solely economic indicators than when they are compared based on the combination of economic and social indicators. The causes of such outcome are explained on the example of Turkey and the United States in the preceding paragraph.
The inefficiency sources and proposed improvements, calculated in the same manner as in the previous models, are presented in Table 7. These values differ significantly from the ones obtained with Models 1 and 2. Thus, in the Model 3 , real per capita GDP had the strongest impact on efficiency only in three years (2007, 2008 and 2011), the inflation rate in one year (2009) and the seats held by women in national parliaments in the remaining six years. On a general level, the requested input and output improvements are not nearly as large as they were in the previous two models, which testify to smoothed differences among the OECD countries when they are viewed in terms of the economic and social indicators combination. During the entire period, it is evident that public health expenditure and inflation rate alternate as indicators are least significantly affecting efficiency.

Sources of Inefficiency - Model 3 (8 Indicators, 10 Windows)

Table 7

\begin{tabular}{|c|c|c|c|c|c|c|c|c|c|c|c|c|c|c|}
\hline \multirow{2}{*}{ V } & \multirow{2}{*}{$\mathrm{r}$} & \multirow{2}{*}{$\mathrm{a}$} & \multirow{2}{*}{$\mathrm{b}$} & \multirow{2}{*}{1} & \multicolumn{10}{|c|}{ Input and output improvements (\%) } \\
\hline & & & & & 2002 & 2003 & 2004 & 2005 & 2006 & 2007 & 2008 & 2009 & 2010 & 2011 \\
\hline \multicolumn{2}{|l|}{ Input } & \multicolumn{3}{|c|}{$\begin{array}{l}\text { Inflation } \\
\text { rate }\end{array}$} & -22.7 & -8.2 & -10.6 & -15.8 & -8.8 & -9.2 & -1.7 & -60.6 & -3.3 & -17.5 \\
\hline \multirow{7}{*}{ Outputs } & \multirow{5}{*}{ Desirable } & \multicolumn{3}{|c|}{$\begin{array}{l}\text { Real per capita } \\
\text { GDP }\end{array}$} & 48.3 & 44.1 & 48.3 & 49.0 & 27.2 & 75.1 & 60.3 & 53.1 & 19.8 & 54.9 \\
\hline & & \multicolumn{3}{|c|}{$\begin{array}{l}\text { Exports/imports } \\
\text { cover ratio }\end{array}$} & 15.0 & 14.1 & 14.2 & 14.1 & 13.1 & 16.8 & 12.5 & 13.6 & 8.2 & 9.0 \\
\hline & & \multicolumn{3}{|c|}{$\begin{array}{l}\text { Scientific and technical } \\
\text { journal articles }\end{array}$} & 40.6 & 42.4 & 45.1 & 47.0 & 33.9 & 47.0 & 33.1 & 25.7 & 18.1 & 38.2 \\
\hline & & \multicolumn{3}{|c|}{$\begin{array}{l}\text { Public health } \\
\text { expenditure }\end{array}$} & 9.8 & 9.1 & 10.0 & 8.6 & 6.6 & 9.7 & 8.5 & 8.4 & 4.8 & 7.1 \\
\hline & & \multicolumn{3}{|c|}{$\begin{array}{l}\text { Seats held by women } \\
\text { in national parliaments }\end{array}$} & 56.9 & 57.8 & 50.3 & 54.3 & 46.1 & 48.1 & 43.9 & 39.8 & 24.2 & 42.9 \\
\hline & \multirow{2}{*}{ Undesirable } & \multicolumn{3}{|c|}{$\begin{array}{l}\text { Unemployment } \\
\text { rate }\end{array}$} & -22.6 & -19.7 & -20.9 & -17.3 & -12.1 & -29.8 & -21.7 & -35.9 & -13.0 & -27.1 \\
\hline & & \multicolumn{3}{|c|}{$\begin{array}{l}\mathrm{CO} 2 \\
\text { emissions }\end{array}$} & -19.5 & -19.0 & -22.2 & -22.1 & -18.4 & -22.5 & -19.8 & -13.0 & -13.9 & -17.8 \\
\hline
\end{tabular}

Source: Author's calculations based on data from the World Bank

The fourth model (Model 4) is the result of the tendency to simultaneously observe all countries in all years, and based on all eight indicators. Hence, it is the most comprehensive model among all four models

Table 8

Efficiency Scores - Model 4 (8 Indicators, 1 Window)

\begin{tabular}{|c|c|c|c|c|c|c|c|c|c|c|c|c|}
\hline \multirow{2}{*}{ Country } & \multicolumn{10}{|l|}{ Year } & \multirow{2}{*}{$\begin{array}{l}\text { Average } \\
\text { per } \\
\text { country }\end{array}$} & \multirow{2}{*}{$\begin{array}{l}\text { Std. } \\
\text { dev. }\end{array}$} \\
\hline & 2002 & 2003 & 2004 & 2005 & 2006 & 2007 & 2008 & 2009 & 2010 & 2011 & & \\
\hline Australia & 0.775 & 0.762 & 0.770 & 0.785 & 0.793 & 0.829 & 0.838 & 0.845 & 0.865 & 0.891 & 0.815328 & 0.044 \\
\hline Austria & 0.881 & 0.868 & 0.865 & 0.869 & 0.875 & 0.880 & 0.894 & 0.892 & 0.888 & 0.892 & 0.880300 & 0.011 \\
\hline Belgium & 0.856 & 0.867 & 0.888 & 0.891 & 0.881 & 0.875 & 0.892 & 0.900 & 0.905 & 0.894 & 0.884950 & 0.015 \\
\hline Canada & 0.811 & 0.816 & 0.821 & 0.823 & 0.816 & 0.823 & 0.826 & 0.840 & 0.824 & 0.831 & 0.823078 & 0.008 \\
\hline Czech Republic & 1 & 1 & 0.992 & 0.982 & 0.974 & 0.960 & 0.939 & 0.951 & 0.962 & 0.963 & 0.972398 & 0.021 \\
\hline Denmark & 0.979 & 0.979 & 0.977 & 0.979 & 0.979 & 0.982 & 0.993 & 0.990 & 0.992 & 1 & 0.984908 & 0.008 \\
\hline Finland & 0.906 & 0.894 & 0.887 & 0.882 & 0.893 & 0.925 & 0.929 & 0.917 & 0.920 & 0.959 & 0.911320 & 0.023 \\
\hline France & 0.939 & 0.919 & 0.917 & 0.916 & 0.915 & 0.920 & 0.920 & 0.981 & 0.945 & 0.975 & 0.934596 & 0.025 \\
\hline Germany & 0.914 & 0.906 & 0.893 & 0.889 & 0.888 & 0.891 & 0.890 & 0.895 & 0.891 & 0.889 & 0.894652 & 0.009 \\
\hline Greece & 0.681 & 0.699 & 0.690 & 0.700 & 0.723 & 0.706 & 0.705 & 0.800 & 0.793 & 0.802 & 0.729878 & 0.048 \\
\hline Hungary & 0.870 & 0.865 & 0.854 & 0.856 & 0.851 & 0.840 & 0.839 & 1 & 1 & 0.929 & 0.890342 & 0.063 \\
\hline Iceland & 0.972 & 0.975 & 0.969 & 0.981 & 0.979 & 1 & 1 & 1 & 1 & 1 & 0.987586 & 0.014 \\
\hline Ireland & 0.882 & 0.896 & 0.892 & 0.887 & 0.880 & 0.883 & 0.887 & 0.980 & 0.867 & 0.872 & 0.892561 & 0.032 \\
\hline Italy & 0.862 & 0.864 & 0.877 & 0.881 & 0.884 & 0.889 & 0.893 & 0.899 & 0.905 & 0.880 & 0.883437 & 0.014 \\
\hline Japan & 0.941 & 0.934 & 0.936 & 0.945 & 0.938 & 0.948 & 0.950 & 0.946 & 0.958 & 0.961 & 0.945626 & 0.009 \\
\hline Korea & 0.779 & 0.769 & 0.782 & 0.783 & 0.809 & 0.797 & 0.783 & 0.778 & 0.743 & 0.763 & 0.778567 & 0.018 \\
\hline Luxembourg & 1 & 0.968 & 0.965 & 0.966 & 0.976 & 1 & 1 & 0.988 & 0.995 & 1 & 0.985789 & 0.015 \\
\hline Mexico & 1 & 1 & 0.992 & 0.971 & 0.974 & 0.957 & 0.944 & 1 & 1 & 0.983 & 0.981999 & 0.020 \\
\hline Netherlands & 0.950 & 0.894 & 0.865 & 0.865 & 0.983 & 0.989 & 1 & 1 & 1 & 1 & 0.954539 & 0.058 \\
\hline
\end{tabular}




\begin{tabular}{|c|c|c|c|c|c|c|c|c|c|c|c|c|}
\hline \multirow{2}{*}{ Country } & \multicolumn{10}{|l|}{ Year } & \multirow{2}{*}{$\begin{array}{l}\text { Average } \\
\text { per } \\
\text { country }\end{array}$} & \multirow{2}{*}{$\begin{array}{l}\text { Std. } \\
\text { dev. }\end{array}$} \\
\hline & 2002 & 2003 & 2004 & 2005 & 2006 & 2007 & 2008 & 2009 & 2010 & 2011 & & \\
\hline "New Zealand & 0.909 & 0.911 & 0.930 & 0.936 & 0.941 & 0.966 & 0.970 & 0.964 & 0.964 & 0.967 & 0.945849 & 0.024 \\
\hline Norway & 1 & 0.993 & 0.991 & 0.997 & 1 & 1 & 1 & 1 & 1 & 1 & 0.998060 & 0.003 \\
\hline Poland & 0.826 & 0.817 & 0.802 & 0.814 & 0.926 & 0.879 & 0.893 & 0.914 & 0.937 & 0.819 & 0.862563 & 0.052 \\
\hline Portugal & 0.852 & 0.839 & 0.850 & 0.838 & 0.838 & 0.826 & 0.891 & 0.915 & 0.983 & 1 & 0.883159 & 0.063 \\
\hline Slovak Republic & 1 & 1 & 0.861 & 0.864 & 0.807 & 0.807 & 0.808 & 0.888 & 0.824 & 0.848 & 0.870673 & 0.073 \\
\hline Spain & 0.831 & 0.833 & 0.843 & 0.845 & 0.851 & 0.854 & 0.865 & 0.912 & 0.937 & 0.936 & 0.870783 & 0.042 \\
\hline Sweden & 0.987 & 0.991 & 0.991 & 0.991 & 1 & 1 & 1 & 1 & 0.995 & 1 & 0.995557 & 0.005 \\
\hline Switzerland & 1 & 0.938 & 0.963 & 0.931 & 0.948 & 1 & 1 & 0.971 & 1 & 1 & 0.975117 & 0.029 \\
\hline Turkey & 1 & 1 & 1 & 1 & 0.943 & 0.919 & 0.929 & 1 & 0.970 & 0.972 & 0.973319 & 0.032 \\
\hline United Kingdom & 0.920 & 0.918 & 0.937 & 0.935 & 0.941 & 0.933 & 0.944 & 0.962 & 0.964 & 0.964 & 0.941841 & 0.017 \\
\hline United States & 0.591 & 0.599 & 0.631 & 0.658 & 0.672 & 0.677 & 0.661 & 0.648 & 0.656 & 0.663 & 0.645724 & 0.029 \\
\hline Average per year & 0.897 & 0.890 & 0.888 & 0.889 & 0.896 & 0.898 & 0.903 & 0.926 & 0.923 & 0.922 & 0.903150 & 0.027 \\
\hline Std. dev. & 0.101 & 0.096 & 0.090 & 0.085 & 0.082 & 0.085 & 0.086 & 0.081 & 0.086 & 0.084 & 0.083004 & 0.019 \\
\hline Minimum score & 0.591 & 0.599 & 0.631 & 0.658 & 0.672 & 0.677 & 0.661 & 0.648 & 0.656 & 0.663 & 0.645724 & 0.003 \\
\hline Maximum score & 1 & 1 & 1 & 1 & 1 & 1 & 1 & 1 & 1 & 1 & 0.998060 & 0.073 \\
\hline $\begin{array}{l}\text { No. (\%) of efficient } \\
\text { countries }\end{array}$ & $\begin{array}{l}7 \\
23 \%\end{array}$ & $\begin{array}{l}4 \\
13 \%\end{array}$ & $\begin{array}{l}1 \\
3 \%\end{array}$ & $\begin{array}{l}1 \\
3 \%\end{array}$ & $\begin{array}{l}2 \\
7 \%\end{array}$ & $\begin{array}{l}5 \\
17 \%\end{array}$ & $\begin{array}{l}6 \\
20 \%\end{array}$ & $\begin{array}{l}7 \\
23 \%\end{array}$ & $\begin{array}{l}6 \\
20 \%\end{array}$ & $\begin{array}{l}8 \\
27 \%\end{array}$ & $\begin{array}{l}0 \\
0 \%\end{array}$ & \\
\hline
\end{tabular}

Source: Author's calculations based on data from the World Bank

used in this research. In this model, as well as in the second one, one ten-year window is used and the efficiency is assessed based on all eight indicators. As well as in the case of Models 1 and 3, the difference between Models 2 and 4 is in the number of the observed indicators.

The highest average efficiency result (0.926) was achieved in 2009, and the lowest (0.888) in 2004. While only one country was efficient for the years 2004 and 2005, even eight of them were efficient for the final year of the observed period. The results produced by this model can be compared to the results of the previous models by two different criteria - the same window length (to the results given by the Model 2) and the same set of indicators (to the results obtained by the Model 3).

As in the case of Models 1 and 3, the average total efficiency score (0.903150) in the model developed based on eight indicators (Model 4) is much higher than that (0.700984) in the model developed based on four indicators (Model 2). Similar to the Model 2, none of the countries has been continuously efficient. Unlike in the Model 2, where only eight out of 300 entities were efficient, in this model, there were 47 efficient entities. Norway was efficient in seven years, Iceland, Sweden, Switzerland, and Turkey in five years, Luxembourg, Mexico and Netherlands in four years, Czech Republic, Hungary and Slovak Republic in two years, and Denmark and Portugal in one year, while the rest of 17 countries showed no efficiency. Also contrary to the Model 2, there was no year in which no country was efficient. The worst of 300 efficiency results (0.591) was registered by the United States in 2002, while in the Model 2 it was Greece in 2003. This confirms the anticipated conclusion about much less pronounced cross-country differences after the incorporation of social indicators. The highest average efficiency scores were recorded by two Scandinavian countries - Norway (0.998060) and Sweden (0.995557), while in the Model 2 it was Norway and Luxembourg with slightly lower efficiency values. As in the case of the models with the window length of one year, and for the same reasons, broadening the set of indicators caused no worsening of the efficiency scores and Turkey achieved the most noticeable shift in average efficiency score $(+0.426379)$.

As the comparison of Models 1 and 2, there are certain resemblances as well as significant dissimilarities between the results generated by Models 3 and 4. As in the Model 3, no country has experienced permanent efficiency growth, and the United States was again on average by far the least efficient country (0.645724), with the worst efficiency results in all ten years observed. Contrary to the Model 3, no country has shown permanent efficiency decline.

To complete the comparison of this model with its predecessors, it is important to accurately determine which inputs and outputs are causing inefficiency and to what extent. The sources of inefficiency, as well as the size of their impact, are presented in Table 9.

Sources of Inefficiency - Model 4 (8 Indicators, 1 Window)

Table 9

\begin{tabular}{|c|c|c|c|c|c|c|c|c|c|c|c|c|c|c|c|}
\hline \multirow{2}{*}{ V } & \multirow{2}{*}{$\mathrm{a}$} & \multirow{2}{*}{$\mathrm{i}$} & \multirow{2}{*}{$\mathrm{a}$} & \multirow{2}{*}{$\mathrm{b}$} & \multirow{2}{*}{$\mathrm{e}$} & \multicolumn{10}{|c|}{ Input and output improvements (\%) } \\
\hline & & & & & & 2002 & 2003 & 2004 & 2005 & 2006 & 2007 & 2008 & 2009 & 2010 & 2011 \\
\hline Input & & & fflation & & & 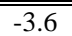 & -3.5 & 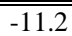 & 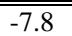 & -13.5 & 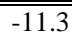 & 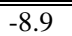 & $2-4.2$ & 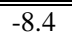 & 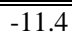 \\
\hline \multirow{7}{*}{$\begin{array}{l}\stackrel{0}{0} \\
\text { 离 }\end{array}$} & \multirow{5}{*}{ 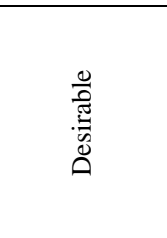 } & \multicolumn{4}{|c|}{ Real per capita GDP } & 60.1 & 60.5 & 64.4 & 65.4 & 66.3 & 66.2 & 64.7 & 51.3 & 56.4 & 58.3 \\
\hline & & \multicolumn{4}{|c|}{ Exports/imports cover ratio } & 14.2 & 16.1 & 17.4 & 17.9 & 19.6 & 17.3 & 17.7 & 13.6 & 14.8 & 13.8 \\
\hline & & \multicolumn{4}{|c|}{$\begin{array}{l}\text { Scientific and technical journal } \\
\text { articles }\end{array}$} & 66.3 & 80.0 & 69.1 & 67.7 & 53.4 & 59.3 & 47.4 & 30.2 & 30.2 & 39.1 \\
\hline & & \multicolumn{4}{|c|}{ Public health expenditure } & 15.0 & 15.4 & 16.1 & 15.5 & 14.5 & 13.9 & 12.8 & 9.8 & 10.2 & 10.4 \\
\hline & & \multicolumn{4}{|c|}{$\begin{array}{l}\text { Seats held by women in national } \\
\text { parliaments }\end{array}$} & 66.4 & 67.7 & 67.5 & 68.4 & 64.9 & 60.9 & 61.0 & 48.5 & 51.6 & 52.7 \\
\hline & \multirow{2}{*}{ Undesirable } & \multicolumn{4}{|c|}{ Unemployment rate } & -25.1 & -28.5 & -30.7 & -28.2 & -26.2 & -20.0 & -17.9 & -29.1 & -32.8 & -29.8 \\
\hline & & & $\mathrm{O} 2 \mathrm{em}$ & sions & & -15.6 & -17.7 & -19.2 & -20.0 & -19.3 & -20.5 & -20.0 & -17.8 & -19.4 & -18.9 \\
\hline
\end{tabular}

Source: Author's calculations based on data from the World Bank 
Even though the efficiency of OECD countries in this model was measured through the prism of the same eight economic and social indicators as in the Model 3, the outcomes of these two models are quite different. Thus, in the Model 4, the most important role in affecting the efficiency in the first four years was divided between scientific and technical journal articles (2003 and 2004) and seats held by women in national parliaments (2002 and 2005), while during the remaining six years that role was taken over by real per capita GDP. Interestingly, the first of these three indicators was not the primary source of inefficiency in the Model 3 even in one year. Also unlike the Model 3 where it was the least significant inefficiency source in six years, public health expenditure had a minimal impact on efficiency in the Model 4 only in the final year, while during the entire remaining period this has been the inflation rate. The model orientation towards outputs initiates generally stronger role of output rather than input variables in achieving efficiency. The fact that, in general terms, the required changes of all seven outputs in this model outgrew those in the Model 3 can be once more attributed to the difference between the window lengths which dictate the number and hence the size of comparison sets. At the same time, the cross-OECD-country disparities in the Model 4 were on average significantly diminished when compared to those in Models 1 and 2, for the earlier mentioned reason of the addition of social indicators. This effect, along with the difference in window lengths, explains the easily observable fact that each of the four models employed resulted in different relative efficiency scores.

Table 10 summarizes the impact of adding the four social indicators to the list of four macroeconomic indicators on the results of the models based on one-year windows. To simplify reporting, the first and second rank orders were averaged to provide a unique ranking for each country. The biggest loser from this turn toward social factors was Korea. This can be explained by Korea's worse than average performance in all four social indicators, which

Country Rankings by Average Efficiency Score, Ten One-Year Windows

Table 10

\begin{tabular}{|c|c|c|c|c|}
\hline Country & Model 1 & Model 3 & Change & $\begin{array}{l}\text { Average } \\
\text { rank order }\end{array}$ \\
\hline Australia & 24 & 27 & -3 & 27 \\
\hline Austria & 13 & 20 & -7 & 17 \\
\hline Belgium & 18 & 25 & -7 & 22 \\
\hline Canada & 19 & 28 & -9 & 24 \\
\hline Czech Republic & 17 & 11 & +6 & 14 \\
\hline Denmark & 11 & 1 & +10 & 7 \\
\hline Finland & 12 & 14 & -2 & 12 \\
\hline France & 22 & 13 & +9 & 18 \\
\hline Germany & 9 & 17 & -8 & 12 \\
\hline Greece & 30 & 29 & +1 & 30 \\
\hline Hungary & 20 & 21 & -1 & 21 \\
\hline Iceland & 6 & 1 & +5 & 5 \\
\hline Ireland & 8 & 16 & -8 & 10 \\
\hline Italy & 21 & 24 & -3 & 23 \\
\hline Japan & 5 & 10 & -5 & 8 \\
\hline Korea & 7 & 18 & -11 & 11 \\
\hline Luxembourg & 1 & 1 & 0 & 1 \\
\hline Mexico & 15 & 1 & +14 & 9 \\
\hline Netherlands & 4 & 1 & +3 & 4 \\
\hline New Zealand & 16 & 12 & +4 & 14 \\
\hline Norway & 1 & 1 & 0 & 1 \\
\hline Poland & 14 & 22 & -8 & 19 \\
\hline Portugal & 28 & 19 & +9 & 24 \\
\hline Slovak Republic & 25 & 23 & +2 & 26 \\
\hline Spain & 26 & 26 & 0 & 28 \\
\hline Sweden & 10 & 1 & +9 & 6 \\
\hline Switzerland & 3 & 1 & +2 & 3 \\
\hline Turkey & 29 & 1 & +28 & 16 \\
\hline United Kingdom & 23 & 15 & +8 & 20 \\
\hline United States & 27 & 30 & -3 & 29 \\
\hline
\end{tabular}

Source: Author's calculations

Table 11

Country Rankings by Average Efficiency Score, One Ten-Year Window

\begin{tabular}{|c|c|c|c|c|}
\hline Country & Model 2 & Model 4 & Change & $\begin{array}{c}\text { Average } \\
\text { rank order }\end{array}$ \\
\hline Australia & 24 & 27 & -3 & 28 \\
\hline Austria & 14 & 22 & -8 & 15 \\
\hline Belgium & 18 & 19 & -1 & 19 \\
\hline Canada & 17 & 26 & -9 & 24 \\
\hline Czech Republic & 19 & 9 & +10 & 13 \\
\hline Denmark & 10 & 5 & +5 & 6 \\
\hline Finland & 13 & 15 & -2 & 13 \\
\hline France & 22 & 14 & +8 & 15 \\
\hline
\end{tabular}




\begin{tabular}{|c|c|c|c|c|}
\hline Country & Model 2 & Model 4 & Change & $\begin{array}{c}\text { Average } \\
\text { rank order }\end{array}$ \\
\hline Germany & 8 & 16 & -8 & 10 \\
\hline Greece & 30 & 29 & +1 & 30 \\
\hline Hungary & 20 & 18 & +2 & 21 \\
\hline Iceland & 3 & 3 & 0 & 2 \\
\hline Ireland & 6 & 17 & -11 & 9 \\
\hline Italy & 21 & 20 & +1 & 23 \\
\hline Japan & 12 & 12 & 0 & 10 \\
\hline Korea & 9 & 28 & -19 & 19 \\
\hline Luxembourg & 2 & 4 & -2 & 2 \\
\hline Mexico & 15 & 6 & +9 & 8 \\
\hline Netherlands & 5 & 10 & -5 & 6 \\
\hline New Zealand & 16 & 11 & +5 & 12 \\
\hline Norway & 1 & 1 & 0 & 1 \\
\hline Poland & 11 & 25 & -14 & 15 \\
\hline Portugal & 29 & 21 & +8 & 27 \\
\hline Slovak Republic & 23 & 24 & -1 & 25 \\
\hline Spain & 26 & 23 & +3 & 26 \\
\hline Sweden & 7 & 2 & +5 & 4 \\
\hline Switzerland & 4 & 7 & -3 & 5 \\
\hline Turkey & 28 & 8 & +20 & 15 \\
\hline United Kingdom & 25 & 13 & +12 & 21 \\
\hline United States & 27 & 30 & -3 & 29 \\
\hline
\end{tabular}

Source: Author's calculations

is particularly evident in the per capita number of scientific and technical journal articles. On the other hand, and for the reasons explained earlier, by far the biggest gainer from this change in point of view was, as expected, the less industrialized Turkey. These drastic oscillations in the rankings once again strongly confirm the influence of the inclusion of social indicators in evaluating the relative macroeconomic performance of nations. Table 11 is analogous to Table 10, but refers to the country rankings in Models 2 and 4. As in the previous case, the inclusion of social indicators had most and least favourable influence on Turkey and Korea respectively. Comparing this impact with the previous one, it can be noted that its magnitude is increased in the case of Korea and decreased in the case of Turkey.

Comparing the average rank orders from Tables 10 and 11 for each country, it can be seen that some countries perform relatively better according to the models based on one-year windows, while the others respond better to models with a ten-year window.

\section{Concluding Remarks}

The relative efficiency of the OECD members was empirically assessed based on the reciprocal performance comparison of thirty countries, using DEA window analysis. The analysis included time-series cross-country comparisons using a ten-year period, thus enabling simultaneous monitoring of the efficiency dynamics of the countries. By employing four models with the assumption of variable returns-to-scale, which differs in the window lengths and the indicator sets, the countries' performances were compared within and between years, integrating economic, social, institutional and environmental objectives.

The empirical results suggest several important findings. Firstly, when it comes to the efficiency scores averaged across all ten years of data collection, Norway was ranked first regardless of the model used. At the same time, Greece performed worst according to the models with only economic indicators, and the United States was ranked last in the models with the combination of economic and social indicators. Secondly, based on the amount of inefficiency for each country, we derived the amount of inefficiency for the OECD countries as a whole. This amount suggests that there are definite possibilities of increasing efficiency levels. The average overall inefficiency hence could be reduced by $5.8 \%$ to $29.9 \%$, depending on the model choice. Thirdly, as a general conclusion, by far the most frequent major source of inefficiency was GDP, while the inflation rate was most commonly the least significant inefficiency source. Main study result is in accordance with most growth econometrics papers (Durlauf et al., 2005) identifying starting GDP level as the most important economic growth determinant. The same result is validated in this study.

The findings of this study, based on cross-country comparisons, should be of interest to analysts and should assist policymakers in each country in identifying the strengths and weaknesses of its socio-economic performance, and thus in designing a targeted socio-economic policy. They give an insight into the level and dynamics of relative efficiency and result in guidelines for creating new or recreating existing socio-economic conditions in OECD countries. To make this insight more comprehensive, the analysis through the proposed models should be expanded to include more countries worldwide, to span over a longer period and to incorporate more indicators that would address many additional aspects of socio-economic development. These possibilities remain open for future investigation. 


\section{Acknowledgment}

This work has been fully supported by the Croatian Science Foundation under the project number 9481 Modelling Economic Growth - Advanced Sequencing and Forecasting Algorithm. Any opinions, findings, and conclusions or recommendations expressed in this material are those of the author(s) and do not necessarily reflect the views of Croatian Science Foundation. Comments from the Editor and two anonymous reviewers are gratefully acknowledged.

\section{References}

Afonso, A., \& St. Aubyn, M. (2013). Public and private inputs in aggregate production and growth - a cross-country efficiency approach. Applied Economics, 45(32), 4487-4502. https://doi.org/10.1080/00036846.2013.791018

Arcelus, F. J., \& Arocena, P. (2000). Convergence and productive efficiency in fourteen OECD countries: a non-parametric frontier approach. International Journal of Production Economics, 66(2), 105-117. https://doi.org/10. 1016/S09255273(99)00116-4

Arcelus, F. J., \& Arocena, P. (2005). Productivity differences across OECD countries in the presence of environmental constraints. Journal of the Operational Research Society, 56(12), 1352-1362. https://doi.org/10.1057/palgrave. jors. 2601942

Banker, R. D., Charnes, A., \& Cooper, W. W. (1984). Some Models for Estimating Technical and Scale Inefficiencies in Data Envelopment Analysis. Management Science, 30(9), 1078-1092. https://doi.org/10.1287/mnsc.30.9.1078

Barla, P., \& Perelman, S. (2005). Sulphur emissions and productivity growth in industrialised countries. Annals of Public \& Cooperative Economics, 76(2), 275-300. https://doi.org/10.1111/j.1370-4788.2005.00279.x

Blazejowski, M., Gazda, J., \& Kwiatkowski, J. (2016). Bayesian Model Averaging in the Studies on Economic Growth in the EU Regions-Application of the gretl BMA package. Economics \& Sociology, 9(4), 168.

Brockett, P. L., Golany, B., \& Li, S. (1999). Analysis of Intertemporal Efficiency Trends Using Rank Statistics with an Application Evaluating the Macro Economic Performance of OECD Nations. Journal of Productivity Analysis, 11(2), 169-182. https://doi.org/10.1023/A:1007788117626

Calmfors, L., \& Driffill, J. (1988). Bargaining structure, corporatism and macroeconomic performance, Economic policy, 3(6), 13-61. https://doi.org/10.2307/1344503

Camarero, M., Castillo, J., Picazo-Tadeo, A. J., \& Tamarit, C. (2013). Eco-efficiency and convergence in OECD countries. Environmental and Resource Economics, 55(1), 87-106. https://doi.org/10.1007/s10640-012-9616-9

Camarero, M., Picazo-Tadeo, A.J., \& Tamarit, C. (2008). Is the environmental performance of industrialized countries converging? A 'SURE' approach to testing for convergence. Ecological Economics, 66(4), 653-661. https://doi.org/10. 1016/j.ecolecon.2007.10.024

Charnes, A., Cooper, W. W., \& Rhodes, E. (1978). Measuring the Efficiency of Decision Making Units. European Journal of Operational Research, 2(6), 429-444. https://doi.org/10.1016/0377-2217(78)90138-81

Cherchye, L. (2001), Using data envelopment analysis to assess macroeconomic policy performance. Applied Economics, 33(3), 407-416. https://doi.org/10.1080/00036840122353

Cooper, W. W., Seiford, L. M., \& Tone, K. (2006). Introduction to Data Envelopment Analysis and Its Uses: With DEASolver Software and References, Springer, New York.

Durlauf, S. N., Johnson, P. A., and Temple, J. R. W. (2005). Growth econometrics. In P. Aghion and S. N. Durlauf (eds.) Handbook of Economic Growth, Volume 1A, North-Holland: Amsterdam, 2005, pp. 555-677. https://doi.org/10.1016 /S1574-0684(05)01008-7

Emrouznejad, A. (2003). An alternative DEA measure: a case of OECD countries. Applied Economics Letters, 10(12), 779782. https://doi.org/10.1080/1350485032000126703

Fare, R., Grosskopf, S., \& Hernandez-Sancho, F. (2004). Environmental performance: an index number approach. Resource and Energy economics, 26(4), 343-352. https://doi.org/10.1016/j.reseneeco.2003.10.003

Fare, R., Grosskopf, S., Norris, M., \& Zhang, Z. (1994). Productivity Growth, Technical Progress, and Efficiency Change in Industrialized Countries. American Economic Review, 84(1), 66-83.

Fidrmuc, J., \& Kostagianni, S. (2015). Impact of Imf Assistance on Economic Growth Revisited 1. Economics \& Sociology, 8(3), 32. https://doi.org/10.14254/2071-789X.2015/8-3/2

Halkos, G. E., \& Tzeremes, N. G. (2009). Exploring the existence of Kuznets curve in countries' environmental efficiency using DEA window analysis. Ecological Economics, 68(7), 2168-2176. https://doi.org/10.1016/j.ecolecon. 2009.02.018

Jakubowska, A., Horvathova, Z. (2016), Economic Growth and Health: A Comparative Study of the EU Countries. Economics and Sociology, 9(3), 158-168. 
Liu, J. S., Lu, L. Y., Lu, W. M., \& Lin, B. J. (2013). Data envelopment analysis 1978-2010: A citation-based literature survey. Omega, 41(1), 3-15. https://doi.org/10.1016/j.omega.2010.12.006

Lovell, C. A. K., Pastor, J. T., \&Turner, J. A. (1995). Measuring macroeconomic performance in the OECD: A comparison of European and non-European countries. European Journal of Operational Research, 87(3), 507-518. https://doi.org/10.1016/0377-2217(95)00226-X

Lu, C. C., Chiu, Y. H., Shyu, M. K., \& Lee, J. H. (2013). Measuring CO2 emission efficiency in OECD countries: application of the hybrid efficiency model. Economic Modelling, 32, 130-135. https://doi.org/10. 1016/j.econmod. 2013.01.047

Makridou, G., Andriosopoulos, K., Doumpos, M., \& Zopounidis, C. (2016). Measuring the efficiency of energy-intensive industries across European countries. Energy Policy, 88, 573-583. https://doi.org/10.1016/j. enpol.2015.06.042

Mardani, A., Jusoh, A., Khalil MD Nor, Khalifah, Z., Zakwan, N., Valipour, A. (2015). Multiple criteria decision-making techniques and their applications - a review of the literature from 2000 to 2014. Economic Research-Ekonomska Istrazivanja, 28(1), 516-571. https://doi.org/10.1080/1331677X.2015.1075139

Maudos, J., Pastor, J. M., \& Serrano, L. (1999). Total factor productivity measurement and human capital in OECD countries. Economics letters, 63(1), 39-44. https://doi.org/10.1016/S0165-1765(98)00252-3

McCracken, P. W. (1977). Towards full employment and price stability, OECD, Paris.

Moesen, W. W., \& Cherchye, L. (1998). The Macroeconomic Performance of Nations: Measurement and Perception, Discussion Paper Series DPS 98.22, Centre for Economic Studies, Catholic University of Leuven.

OECD (2001). OECD Science, Technology, and Industry Scoreboard, OECD, Paris.

Okun, A. M. (1970). The political economy of prosperity. Brookings Institute Press.

Rashidi, K., \& Saen, R. F. (2015). Measuring eco-efficiency based on green indicators and potentials in energy saving and undesirable output abatement. Energy Economics, 50, 18-26. https://doi.org/10.1016/j.eneco.2015.04.018

Rashidi, K., Shabani, A., \& Saen, R. F. (2015). Using data envelopment analysis for estimating energy saving and undesirable output abatement: a case study in the Organization for Economic Co-Operation and Development (OECD) countries. Journal of Cleaner Production, 105, 241-252. https://doi.org/10.1016/j.jclepro.2014.07.083

Simionescu, M. (2013). The use of VARMA models in forecasting macroeconomic indicators. Economics \& Sociology, 6(2), 94. https://doi.org/10.14254/2071-789X.2013/6-2/9

Simionescu, M., Dobes, K., Brezina, I., \& Gaal, A. (2016). GDP rate in the European Union: simulations based on panel data models. Journal of International Studies, 9(3), 191-202.

Simsek, N. (2014). Energy efficiency with undesirable output at the economy-wide level: cross-country comparison in OECD sample. American Journal of Energy Research, 2(1), 9-17. https://doi.org/10.12691/ajer-2-1-2

Sueyoshi, T., Yuan, Y., \& Goto, M. (2017). A Literature Study for DEA Applied to Energy and Environment. Energy Economics, (62), 104-124. https://doi.org/10.1016/j.eneco.2016.11.006

Streimikiene, D., Mikalauskiene, A., \& Mikalauskas, I. (2016). Comparative Assessment of Sustainable Energy Development in the Czech Republic, Lithuania and Slovakia. Journal of Competitiveness, 8 (2), 31-41. https://doi.org/10.7441/joc.2016.02.03

Woo, C., Chung, Y., Chun, D., Seo, H., \& Hong, S. (2015). The static and dynamic environmental efficiency of renewable energy: A Malmquist index analysis of OECD countries. Renewable and Sustainable Energy Reviews, 47, $367-376$. https://doi.org/10.1016/j.rser.2015.03.070

Zaim, O., \& Taskin, F. (2000). Environmental efficiency in carbon dioxide emissions in the OECD: A non-parametric approach. Journal of Environmental Management, 58(2), 95-107. https://doi.org/10.1006/jema.1999.0312

Zhou, P., \& Ang, B. W. (2008). Linear programming models for measuring economy-wide energy efficiency performance. Energy Policy, 36(8), 2911-2916. https://doi.org/10.1016/j.enpol.2008.03.041

Zhou, P., Ang, B. W., \& Poh, K. L. (2006). Slacks-based efficiency measures for modeling environmental performance. Ecological Economics, 60(1), 111-118. https://doi.org/10.1016/j.ecolecon.2005.12.001

Zhou, P., Poh, K. L., \& Ang, B. W. (2007). A non-radial DEA approach to measuring environmental performance. European Journal of Operational Research, 178(1), 1-9. https://doi.org/10.1016/j.ejor.2006.04.038

Zofio, J. L., \& Prieto, A. M. (2001). Environmental efficiency and regulatory standards: The case of CO2 emissions from OECD industries. Resource and Energy Economics, 23(1), 63-83. https://doi.org/10.1016/S0928-7655(00)00030-0

The article has been reviewed.

Received in July, 2017; accepted in October, 2017. 